\title{
Delignification of Valuable Timbers decayed by India Lignicolous fungi
}

\author{
Praveen Kumar Nagadesi ${ }^{1, *}$, Arun Arya ${ }^{2}$ \\ ${ }^{1}$ Department of Botany, P.G College, Andhra Loyola College, Vijayawada - 520008, \\ Andhra Pradesh, India \\ ${ }^{2}$ Department of Botany, Faculty of Science, The Maharaja Sayajirao University of Baroda, \\ Vadodara - 390002, Gujarat, India \\ *E-mail address: nagadesipraveenkumar@yahoo.com
}

\begin{abstract}
ABATRACT
Wood degrading capacity of lignicolous fungi was studied by decay test. In which two methods were followed, i) wood chips method ii) wood block method. Eight timbers infected by six fungi were selected for studying percentage of decay and biochemical test was done to know delignification. After 12 months, $90 \%$ of wood block of T. arjuna was decayed by L. stereoides. In teak wood 16.82 $\%$ of decay was due to $H$. apiaria in 3 months. As the percentage of moisture was less, percentage of weight loss was also less; this indicated that decay capacity of fungi will depends on \% moisture content in wood. The percentage loss in hot water soluble substrates was more in case of $T$. crenulata due to L. stereoides for 5 months, whereas lowest in case of teak wood decayed by H. apiaria for 5 months. The percentage loss in ethanol benzene soluble substrate was more in case of Adina wood decayed by $C$. versicolor for 5 months, whereas lowest in case of teak wood infected with $L$. stereoides for 3 months. As the incubation period increases, percentage loss in acid soluble lignin was more in case of infected woods. L. stereoides, C. versicolor, and H. apiaria showed selective delignification in all infected woods, whereas $T$. pini showed simultaneous degradation of lignin in all woods tested. The valuable timber like teak wood was not resistant to wood decay because they loss $50 \%$ of lignin. The in vitro wood decay test can't be taken as absolute evidence for wood decay behavior of lignin-degrading fungi, so we should conform decay of wood by consider biochemical test. For rapid evaluation of wood decay the wood chip method was best suitable. For the first time the wood decay and biochemical test of 8 wood samples infected by white rot fungi like S. commune, L. stereoides, H. apiaria, C. versicolor, T. pini and soft rot fungi like $T$. viride was studied.
\end{abstract}

Keywords: Biochemical; Delignification; Lignicolous fungi; Wood decay; Teak

\section{INTRODUCTION}

Wood was a very important byproduct, produced by different biological processes in tree. It was an important natural resource from forests which can contribute greatly to climate change and biodiversity conservation (Kaimowitz D. 2003). Based on the FAO definition there are around 3.7 billion ha of forests in the world. Majority of forest was natural forests, in which more than $50 \%$ in South America and Europe, while plantations cover only 187 million ha, representing $5 \%$ of the total forested area (FAO 2007). Global wood consumption was increasing but at a relatively low pace. In the last 20 years the average global 
consumption of wood increased on average only $0.3 \%$ per year, and the estimated annual wood consumption was now around 3.5 billion cubic meters (ITTO 2006). Out of this total volume approximately $50 \%$ are classified as industrial logs. The global consumption of industrial roundwood would achieve around 1.9 billion by the year 2010 (FAO 2007).

The total forest cover in India according to the latest State of Forest Report 2011 is 78.29 million ha and this constitutes $23.81 \%$ of the geographic area. The state of Gujarat was one of the progressive states in western part of India, with an area of 78,687 sq mi $\left(203,800 \mathrm{~km}^{2}\right)$. While recorded forest area is 18,962 sq. $\mathrm{km}$. which was $10 \%$ of total geographical area. The production of fuel and timber was much less than the demand. The forest area which produces timber and fuel wood was only $63.5 \%$ of the recorded area. Lignicolous fungi belonging to Aphyllophorales were economically important, as many of these were pathogens of forest trees and cause serious damage (Natarajan K. and Kolandavelu K. 1998). The forest wood cell wall was composed of cellulose, hemicelluloses and lignin. Cellulose was most consistent of structural components varying minimally between wood species. Lignin and hemicelluloses, however, vary both in composition and amounts not only between hard woods and conifers but also among hardwoods (Timells $\mathrm{T}$. 1967). Cellulose was a long chain polymer of glucose anhydride units joined by $\beta 1-4$ linkages. In general, cellulose components of wood are light in colour, have strong affinity for water and were soft and tough. Hemicelluloses consist of similar polymers of glucose joined by other linkages or polymers of monosaccharide's other than glucose. Lignin was quite different from celluloses and hemicelluloses and was also most resistant to biodegradation. It was three dimensional amorphous, branched polymers of phenyl-propane units joined by a variety of inter-units linkages (Alder E. 1977).

Delignification was deterioration of timber brought about by chemical breakdown and separation of the cell walls of timber. It was also known as "Defibration of Timber". Timer decay was caused by primarily enzymatic activities of microorganisms. Lignicolous fungi were responsible for decay in timber and those fungi that feed on the cell contents, causing stains. These fungi seriously weather timber, ultimately rendering it valueless by consuming cell wall constituents and lead to the disintegration of wood tissue (Desch, H.E. and Dinwoodie, J. M. 1996). Three general types of decay were recognized (Blanchette, R.A. 1991, Eaton, R. A., and Hale M. D. C. 1993, Zabel, R. A., and Morrell J. J. 1992). In white rot, all cell-wall constituents was degraded. Two forms of white rot were distinguished. In selective delignification, polyoses (=hemicelluloses) and lignin were preferentially attacked, especially in early stages. In simultaneous white rot, carbohydrates and lignin were attacked more or less uniformly (Blanchette, R.A. 1991). In brown rot, carbohydrates were extensively removed, but lignin was degraded only to a limited extent (Wilcox, W. W.1968). Soft rot, most recently described type of wood decay, has proven difficult to define and differentiate from other decays. It was caused by Ascomycetes and Deuteromycetes, All cell wall constituents may be degraded during soft rot, but there was usually a preference for carbohydrates, especially in hardwoods (Eslyn, W. E., Kirk T. K., and Effland M. J. 1975, Nilsson, T. Daniel T. G., Kirk T. K., and Obst J. R. 1989).

A better understanding of diverse kinds of lignicolous fungi and their decay types will support efforts to prevent and control wood decay as well as recent efforts to find biotechnological applications of such fungi in the pulp and paper and other industries (Kirk, T. K., and H.M. Chang. 1990). Blanchette (1984) mentioned about lignicolous fungi that remove lignin selectively without appreciable losses of cellulose were extremely attractive for use in biological pulping processes. Such knowledge may also provide perspective in considering evolution of wood-decay capability in various groups of fungi. Our objectives 
were to 1) survey lesser-known and previously neglected lignicolous fungi for the ability to cause wood decay; 2) elucidate the wood decay and biochemical features of decayed wood by such fungi in comparison with known decay types; 3) decay classification of lignicolous fungi, and; 4) Quick identification of wood decay by different test. In the present paper wood degrading capacity of lignicolous fungi was studied by decay test like wood chip and wood block method. Wood of Tectona grandis, Terminalia arjuna, T. bellerica, T. crenulata, Adina cordifolia, Dalbergia sissoo, Pinus longifolia, and Acacia arabica were selected on the value of timber. Lignicolous fungi like $S$. commune, L. stereoides, H. apiaria, C. versicolor, $T$. pini and soft rot fungi like $T$. viride were used to infect wood chips, blocks and logs of above timbers and these were chemically analyzed.

\section{MATERIALS AND METHODS}

Wood degrading capacity of lignicolous fungi was studied by decay test. In which two methods were followed, i) wood chips method ii) wood block method. In biochemical analyses the degraded wood samples were analyzed for water content, $\mathrm{pH}$ of samples, solubility in hot water, and ethanol-benzene, acid insoluble lignin and chlorite holocellulose (Dill, I.; Kraepelin, G. 1986).

\section{1. Wooden chips method}

A survey was undertaken in forests and sawmills of Gujarat, India, during January 2007 to July 2011, to find out occurrence of lignicolous fungi. These fungi were isolated by PDA medium from sporophore and decayed wood and were grown on $2 \%$ malt extract agar in petriplates for $7 \mathrm{~d}$ prior to inoculation in decay chambers. Seven woods like $T$. grandis, $T$. arjuna, T. bellerica, A. cordifolia, D. sissoo, P. longifolia, and A. arabica wooden chips $(0.5 \mathrm{~g})$ were added to decay chamber containing Modified Asthana and Hawker's medium ' $\mathrm{A}$ '. The composition of medium was $10 \mathrm{~g}$ of $\mathrm{D}$ - glucose, $3.5 \mathrm{~g}$ of $\mathrm{KNO}_{3}, 1.75 \mathrm{~g}$ of K $\mathrm{KH}_{2} \mathrm{PO}_{4}$, $0.75 \mathrm{~g}$ of $\mathrm{MgSO}_{4} \cdot 7 \mathrm{H}_{2} \mathrm{O}$ and $20 \mathrm{~g}$ of Agar. The decay chambers were sterilized at $121{ }^{\circ} \mathrm{C}$ for 1 h. The decay chambers were inoculated with Lignicolous fungi like $S$. commune, $L$. stereoides. H. apiaria and soft rot fungi like $T$. viride. Three decay chambers were used for each isolated lignicolous fungi per wood and the fungus inoculated in decay chamber without wooden chips served as control. Assembled decay chambers were incubated in the dark for 20 and $40 \mathrm{~d}$ at $27 \pm 1{ }^{\circ} \mathrm{C}$. The wooden chips were filtered, oven dried, and weighed. Percent weight loss was determined as follows:

$$
\text { Percent weight loss }=\frac{\text { Weight loss of oven }- \text { dried wood after incubation }}{\text { Weight of oven }- \text { dried original wood }} \times 100
$$

Each set of treatment was run in triplicates and average weight loss was always taken as standard value for comparison of wood decay. The weight loss results were statistically analyzed by using the MS office Excel software and the significant values were taken for study. 


\section{2. Wooden block method}

Timber decay caused by Lignicolous fungi like S. commune, L. stereoides. H. apiaria $C$. versicolor and soft rot fungi like $T$. viride was observed in wood blocks of $T$. grandis and T. arjuna and T. bellerica for 20 days to 1year. These fungi were grown on $2 \%$ malt extract agar for $7 \mathrm{~d}$ prior to inoculation. The PDA plates were prepared by inoculating each isolate of above fungi and incubated for 7-10 $\mathrm{d}$.

Totally 12 wooden blocks $(1 \times 1 \times 1 \mathrm{~cm})$ per wood per each lignicolous fungi were cut from the respective logs and soaked in distilled water for $30 \mathrm{~min}$. These wooden blocks were autoclaved. After completely spreading of above fungus, four blocks of each wood were placed on the medium per plate and incubated for 3,6 and 12 months at $27 \pm 1{ }^{\circ} \mathrm{C}$. To maintain moisture in test plates two layers of Whatmen filter paper No 1 were placed on the surface of blocks. The sterile distilled water was added to it regularly. The un-inoculated wooden blocks acted as control. After completion of incubation period each block was cleaned (of the mycelium), oven dried and weighed. The percentage weight loses was calculated as described above.

\section{3. Spawn preparation}

For spawn preparation a media used for developing sporophores of wood rot fungi as suggested by Etter (1929) was used. The spawn preparation medium consisted of $48 \mathrm{~g}$ of corn-meal, $16 \mathrm{~g}$ of corn-starch and $8 \mathrm{~g}$ of powdered wood. The spawn was taken in a polypropylene bag and $2.5 \%$ malt extract was added. The bag was closed by putting the moist cotton swab to maintain moisture level inside the bag; such bags were sterilized at 121 ${ }^{\circ} \mathrm{C}$ for $1 \mathrm{~h}$ and inoculated with four test fungi like L. stereoides $C$. versicolor $H$. apiaria $T$. pini. The bags were incubated in dark for $15 \mathrm{~d}$ at $27 \pm 1{ }^{\circ} \mathrm{C}$. The fully-grown spawn was used for artificial inoculation in wooden logs.

\section{4. Wooden log preparation}

The wood $\log$ of $T$. grandis, A. cordifolia, T. crenulata and T. arujna were infected with above lignicolous fungi and used for biochemical analysis. The average size of (4) wood plank used was $2 \times 2 \times 30 \mathrm{~cm}$ length. The bark was not removed. It helps to maintain moisture and keeps away the foreign fungi. A 5/16" drill bit was used to make holes in the logs for insertion of spawn as diamond drilling pattern. After drilling the entire log was autoclaved for $1 \mathrm{~h}$. After autoclaving spawn was inoculated into the holes. It was then sealed off with paraffin wax. Logs were covered with cheese cloth to maintain moisture, packed in polythene bags and incubated in dark for 12 months.

\section{5. Bio - chemical analysis of decayed wood}

The chemical composition of sound and decayed wood as determined by previously described technique (Dill, I.; Kraepelin, G.1986). Decayed wood was dried at $105{ }^{\circ} \mathrm{C}$ and then ground to pass through a $60 \mu$ mesh screen. It was used for further analysis.

\section{5. 1. Water content}

To obtain water present in the sample decayed wood $(3 \mathrm{~g})$ was dried at $105{ }^{\circ} \mathrm{C}$ for about $48 \mathrm{~h}$, cooled in a desiccator and weighed. The difference in two weights gave the water content in milligrams. 


\subsection{2. pH of samples}

The $\mathrm{pH}$ was determined potentio-metrically after suspension of the samples in distilled water for about 30 to $45 \mathrm{~min}$. Analysis of decayed wood was made with a few grams of fresh material and that of corresponding sound wood was made with $1 \mathrm{~g}$ of dry wood meal.

\section{5. 3. Solubility in hot water}

One gram of dry wood meal was placed in a $250 \mathrm{ml}$ Erlenmeyer flask. After addition of $100 \mathrm{ml}$ of distilled water, the mixture was slowly stirred at $80^{\circ} \mathrm{C}$ for $3 \mathrm{~h}$. The samples were then filtered by using Whatman filter paper No 1, washed with hot water, dried at $105^{\circ} \mathrm{C}$ for about $24 \mathrm{~h}$, cooled in desiccator and weighed.

\section{5. 4. Solubility in ethanol - benzene}

About $1.5 \mathrm{~g}$ of dry wood meal was extracted with ethanol - benzene $(1: 2 \mathrm{v} / \mathrm{v})$ for $4 \mathrm{~h}$ in a Soxhlet extractor, keeping the liquid boiling briskly. Each extracted sample was washed with 50 to $100 \mathrm{ml}$ of ethanol and dried at $105^{\circ} \mathrm{C}$. After evaporation of solvent, each extract was dried at $105^{\circ} \mathrm{C}$ for $24 \mathrm{~h}$, cooled in desiccator and weighed.

\section{5. 5. Acid insoluble lignin (klason lignin)}

Flasks containing $1 \mathrm{~g}$ of ethanol - benzene extracted wood meal and $20 \mathrm{ml}$ of $\mathrm{H}_{2} \mathrm{SO}_{4}$ (72\%) were gently shaken in a water bath at $30{ }^{\circ} \mathrm{C}$ for $1 \mathrm{~h}$. The acid was then diluted with $\mathrm{H}_{2} \mathrm{O}$ to $4 \%$ (wt/vol), and the samples were autoclaved at $121{ }^{\circ} \mathrm{C}$ for $30 \mathrm{~min}$. The lignin that settled overnight was quantitatively collected by filtration through a Whatman filter paper No. 1, washed free of acid with hot water, and dried. The lignin content was calculated as a percentage of oven-dried, non-extracted wood meal.

\section{5. 6. Chlorite holocellulose (CHC)}

Chlorite holocellulose was also determined as described by Seifert 91983). Extracted wood samples of approximately $400 \mathrm{mg}$ were placed in $50 \mathrm{ml}$ Erlenmeyer flasks. Seven milliliters of buffer solution consisting of $60 \mathrm{ml}$ glacial acetic acid and $1.3 \mathrm{~g}$ sodium hydroxide per $1000 \mathrm{ml}$ distilled water was added to each flask. Three milliliters of $20 \%$ $(\mathrm{w} / \mathrm{w})$ aqueous solution of sodium chlorite was immediately added and the flasks were sealed with paraffin wax and aluminum foil. The flasks were placed in an orbital shaker at $110 \mathrm{rpm}$ at $45{ }^{\circ} \mathrm{C}$ for 36 to $40 \mathrm{~h}$. after incubation period; flasks were placed in ice bath to stop the reaction. The contents were then transferred to pre weighed Whatman filter paper No. 1 using $100 \mathrm{ml}$ of $1 \%$ acetic acid. The holocellulose was washed with $5 \mathrm{ml}$ of acetone three times and oven dried at $105^{\circ} \mathrm{C}$ for 4 to $6 \mathrm{~h}$ before weighing.

\section{RESULTS AND DISCUSSION}

\section{1. Wooden chips method}

Percentage decay of seven different woods caused by $S$. commune, L. stereoides. $H$. apiaria (White rot fungi) and T. viride (soft rot fungi) was observed. As compared to other white rot and soft rot fungi, teak and sissoo wood was efficiently degraded by L. stereoides, where the percentage weight loss was 34.6 and $44.6 \%$ after 40days. Whereas in case of $T$. arjuna, T. bellerica, A. cordifolia, A. arabica, and $P$. longifolia woods were efficiently 
degraded by $H$. apiaria, where the percentage weight loss was $62.0,66.4,60.4,52.5$ and 65.4 $\%$ respectively in 40 days. When compared to the all wood decayed after 40 days of incubation, $S$. commune showed $29.1 \%$ decay in A. arabica, whereas the L. stereoides showed $54.3 \%$ decay in $T$. arjuna. The fungus $H$. apiaria showed $66.4 \%$ decay in $T$. bellerica, while $T$. viride showed $22.3 \%$ decay incase of $A$. arabica. The minimum amount of decay was observed in teak wood i.e $3.9 \%$ in 20 days by $S$. commune (Table 1 and Histogram 1).

Table 1. Percentage weight loss of wood chips of seven woods by four Lignicolous fungi.

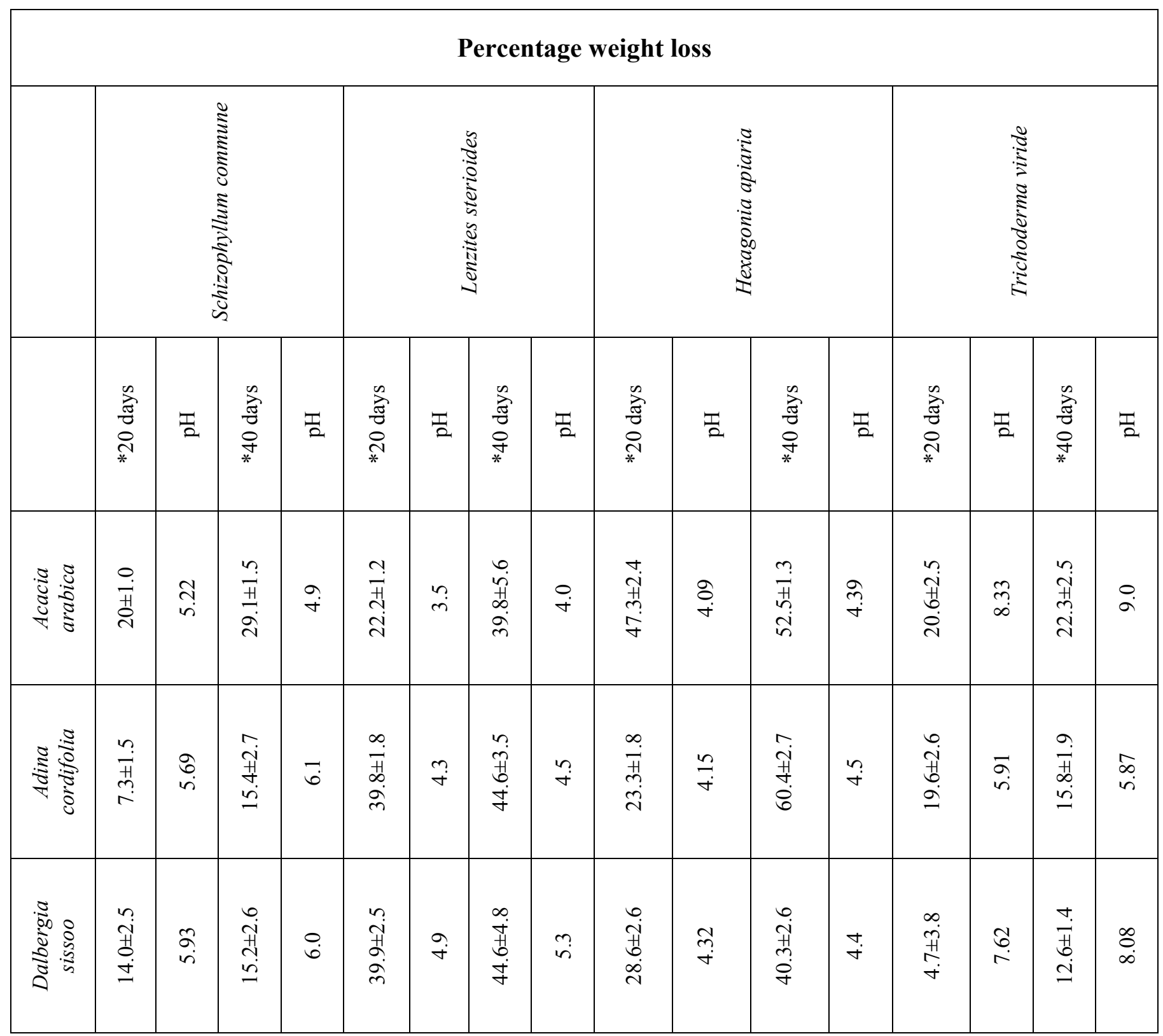




\begin{tabular}{|c|c|c|c|c|c|c|c|c|c|c|c|c|c|c|c|c|}
\hline 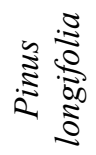 & $\begin{array}{l}0 \\
\text { से } \\
\infty \\
\text { i } \\
\text { in }\end{array}$ & 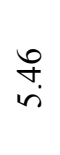 & $\begin{array}{l}m \\
\text { in } \\
\text { Oे } \\
\ddot{n}\end{array}$ & $\begin{array}{l}\ddot{r} \\
\dot{n}\end{array}$ & 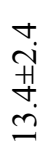 & 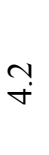 & 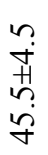 & $\stackrel{\vec{r}}{\dot{m}}$ & $\begin{array}{l}\infty \\
\stackrel{+}{+} \\
\stackrel{+}{+} \\
\dot{f}\end{array}$ & $\underset{+}{\widetilde{\sigma}}$ & $\begin{array}{l}m \\
n \\
y \\
\forall \\
0 \\
0\end{array}$ & $\begin{array}{l}\text { N̦ } \\
\text { in }\end{array}$ & 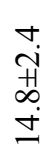 & $\begin{array}{l}\Delta \\
\stackrel{\sigma}{0}\end{array}$ & $\begin{array}{l}0 \\
\text { i } \\
\infty \\
\infty \\
\infty \\
0\end{array}$ & $\stackrel{\text { : }}{0}$ \\
\hline 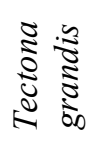 & $\begin{array}{l}\hat{o} \\
\dot{0} \\
\dot{m}\end{array}$ & $\begin{array}{l}\text { ஜ̂. } \\
\text { nn. }\end{array}$ & 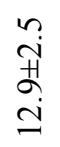 & in & $\begin{array}{l}n \\
\text { in } \\
\frac{\dot{n}}{n}\end{array}$ & $\stackrel{\vartheta}{+}$ & 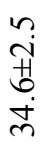 & $\stackrel{\circ}{+}$ & 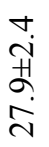 & $\stackrel{\text { ra }}{+}$ & $\begin{array}{l}\text { mi } \\
\text { Hे } \\
m \\
\infty \\
\infty\end{array}$ & $\begin{array}{l}\text { ì } \\
\text { in }\end{array}$ & 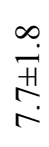 & $\stackrel{ \pm}{m}$ & $\begin{array}{l}\stackrel{\infty}{+} \\
\stackrel{H}{=}\end{array}$ & $\stackrel{8}{\circ}$ \\
\hline 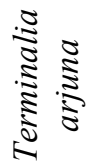 & $\begin{array}{l}n \\
i \\
i \\
\infty \\
\infty \\
\end{array}$ & సુ. & $\begin{array}{l}\infty \\
\dot{\vec{H}} \\
\infty \\
\dot{\sim}\end{array}$ & $\overbrace{0}^{\circ}$ & 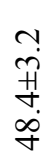 & $\begin{array}{l}\stackrel{0}{ } \\
\text { in }\end{array}$ & 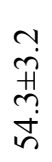 & $\overrightarrow{r i}$ & 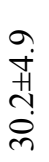 & $\underset{+}{\stackrel{\sim}{*}}$ & $\begin{array}{l}\overrightarrow{0} \\
\text { ते } \\
\text { } \\
\text { b }\end{array}$ & $\begin{array}{l}\text { nn } \\
\text { in }\end{array}$ & $\begin{array}{l}\stackrel{r}{+} \\
\stackrel{H}{+}\end{array}$ & $\begin{array}{l}\infty \\
\infty \\
\infty \\
\infty\end{array}$ & $\begin{array}{l}\stackrel{7}{0} \\
\text { تै } \\
\text { in }\end{array}$ & $\hat{\alpha}$ \\
\hline 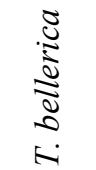 & $\begin{array}{l}0 \\
\text { in } \\
\text { Hy } \\
\text { n }\end{array}$ & $\begin{array}{l}\hat{a} \\
\text { in }\end{array}$ & $\begin{array}{l}\text { ? } \\
\text { Hु } \\
\text { I }\end{array}$ & $\begin{array}{l}\infty \\
\dot{r}\end{array}$ & $\begin{array}{l}\infty \\
\ddot{j} \\
\alpha \\
\dot{y}\end{array}$ & $\stackrel{+}{+}$ & $\begin{array}{l}\text { ? } \\
\dot{H} \\
\dot{0} \\
\dot{H} \\
\text { in }\end{array}$ & $\stackrel{m}{\forall}$ & 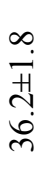 & $\stackrel{\sim}{\sim}$ & $\begin{array}{l}0 \\
0 \\
+1 \\
+8 \\
8 \\
8\end{array}$ & $\underset{\stackrel{\sim}{\sim}}{\stackrel{\sim}{+}}$ & $\begin{array}{l}\overrightarrow{\vec{I}} \\
\vec{I} \\
\vec{I}\end{array}$ & 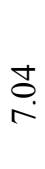 & \begin{tabular}{l}
$n$ \\
\multirow{1}{*}{} \\
0 \\
0 \\
0
\end{tabular} & $\underset{\infty}{\stackrel{\sim}{\sim}}$ \\
\hline
\end{tabular}

* indicates each component values are based on the three replicates. Uninoculated wooden blocks were incubated for 20 and 40 days to act as a control.

\pm Results were significant at $\mathrm{P}<0.05$ level by one way ANOVA

Histogram 1. The \% weight loss in different woods chips infected with four lignicolous fungi.

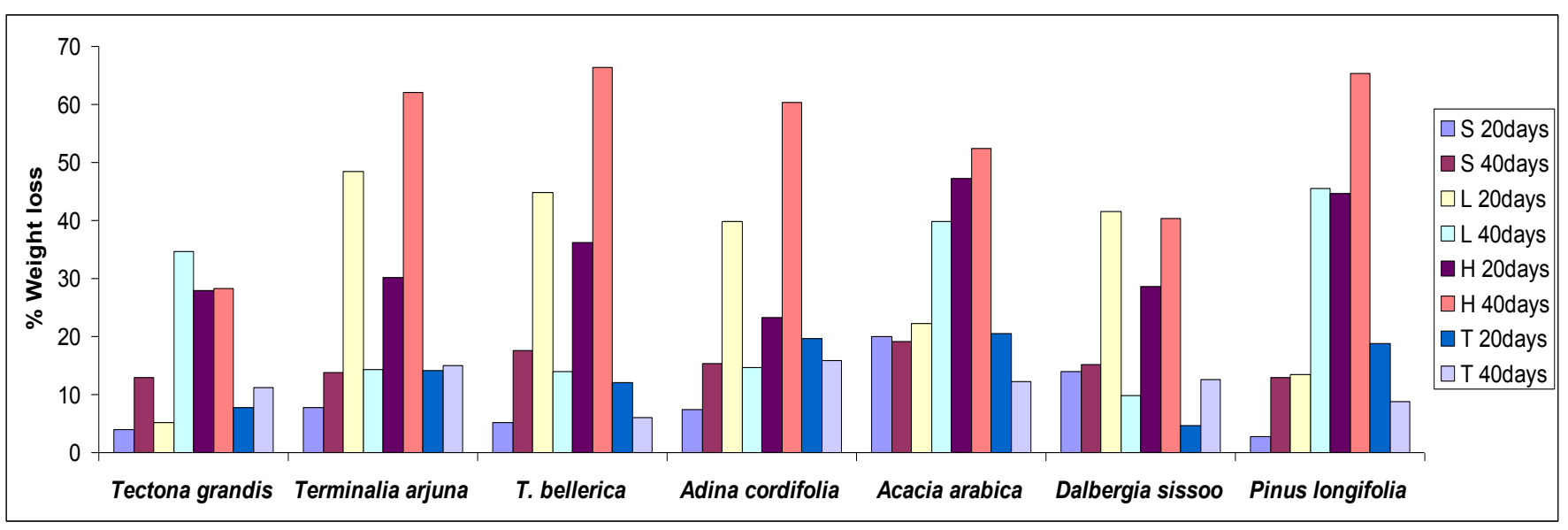

According to ASTM (1969) method of classification of decay resistant classes, teak wood was very resistant in case of $T$. viride, and Lenzites sp. up to 3 weeks of incubation. Moderate resistance was observed in case of H. apiaria and L. stereoides (Nagadesi P. K., Arya A., Albert S. 2013). Bakshi et al. (1967) conducted wood decay test with Polyporus 
hirsutus Fr., P. sanguineus L. ex Fr., P. versicolor L. ex. Fr., P. palustris B. \& C. and Irpex flavus Klotzsch. The results showed that in case of teak wood outer heart wood varies in decay resistance from very resistance to moderate resistance (weight loss 1.98-25.63\%) (Bakshi et al 1967). In the present study teak wood was resistant to moderately resistant when different wood rotting fungi were tested in wood chip method.

The Basidiomycetes plus composite inocula caused significantly more weight loss of inoculated wood chips than members of Basidiomycetes alone after 5 months (Blanchette R.A. and Shaw C.G. 1978). In the present study the lignicolous fungi like S. commune, $L$. stereoides. H. apiaria and soft rot fungi like $T$. viride alone showed significant decay in wood chips after 40 days. Wood chips from slash less than 1 and 2 year old were approx. $40 \%$ decayed by the brown rot fungus $P$. placenta for 5 months. The decay caused by the white rot fungus, $C$. versicolor was approximately half than the $P$. placenta. Hirschioporus abientinus caused approximately $20 \%$ weight loss in wood chips in less than 1 year old but $10 \%$ in 1 and 2 year old chips (Blanchette R.A. and Shaw C.G. 1978). In the present study the increase in weight loss by $H$. apiaria $66.4 \%$ in $T$. bellerica for 40 days. Whereas soft rot fungi like $T$. viride showed $22.3 \%$ weight loss in $A$. arabica for 40 days.

The wood chips of ten-year old plantation of Pinus caribaea (morelet) were inoculated separately with two species of white-rot fungi; Coriolopsis polyzona and Pleurotus squarrosulus, and two species of brown rot fungi; Lentinus lepideus and Gleophyllum striatum. Wood weight loss due to biodegradation varied from 1.5-48.1 \% for Coriolopsis polyzona, 9.6-58.0 \% for Pleurotus squarrosulus, 40.4-78.1\% for Lentinus lepideus and 6.8$49.2 \%$ for Gleophyllum striatum degrading activities (Emerhi, E. A., Ekeke, B. A. and Oyebade, B. A. 2008). In the present study the weight loss due to degradation varied from one to $13 \%$ for $S$. commune, 1 to $45.5 \%$ for L. stereoides, 1-65.4 \% for H. apiaria and 1$18.8 \%$ for $T$. viride in 40days. The highest decay was shown by $H$. apiaria with $27.9 \%$ weight loss in 20 days. The lowest decay was showed in case of $T$. viride with $4.7 \%$ weight loss in 20 days (Nagadesi P. K., Arya A., Albert S. 2013). In the present study teak and sissoo woods were efficiently degraded by $L$. stereoides, whereas, the percentage weight loss was 34.6 and 44.6 in 40 days and T. arjuna, T. bellerica, A. cordifolia, A. arabica, and $P$. longifolia these woods were efficiently degraded by $H$. apiaria whereas the percentage weight loss was $62.0,66.4,60.4,52.5$ and $65.4 \%$ respectively in 40 days only observed.

The molecular structure of wood suggests that cellulose a structural component thereof could be bio-recycled into glucose, a fermentable sugar (Reddy N. and Yang Y. 2009). Cellulase, a multi-component enzyme system produced by soft rot fungi such as $T$. viride and Aspergillus niger exhibits the ability to saccharify cellulose. These enzymes have been proved to be effective in the bioconversion of wood products such as wastepaper into fermentable sugars (van Wyk J. P. H. 2001). In the present paper the ability of soft rot fungi to degrade lignin was proved by wood chip test. The various sawdust wood samples were exposed to $T$. viride cellulase action with the delignified cellulose component bio-converted into fermentable sugars such as glucose (Bohdan V, Yaser D 2011). In the present study the $T$. viride showed significant weight loss in seven woods so it may be used for saccharify cellulose.

\section{2. Wooden block method}

Wood decay caused by four test organisms was observed in wood blocks of $T$. grandis and T. arjuna wood blocks after every 20, 40 and 60 days. The maximum decay was shown by $L$. stereoides in case of T. arjuna after 60 days. The minimum decay was observed in case of $T$. arjuna due to $S$. commune after 20 days. In initial stages of decay, percentage of 
moisture was more whereas in advanced stages of decay the \% moisture reduced. As the percentage moisture was less the percentage weight loss was also less, this indicates that the decay capacity of lignicolous fungi depends on the \% moisture content in wood (Table 2 and Histogram 2).

Table 2. Moisture loss and weight loss of two different wood blocks caused by three lignicolous fungi.

\begin{tabular}{|c|c|c|c|c|c|c|}
\hline & \multicolumn{6}{|c|}{ Schizophyllum commune } \\
\hline & \multicolumn{2}{|c|}{20 days } & \multicolumn{2}{|c|}{40 days } & \multicolumn{2}{|c|}{60 days } \\
\hline Wood & $\begin{array}{l}\% \text { Moisture } \\
\text { Loss* }\end{array}$ & $\begin{array}{l}\% \text { wt. } \\
\text { loss* }\end{array}$ & $\begin{array}{c}\% \text { moisture } \\
\text { loss* }\end{array}$ & $\begin{array}{l}\% \text { wt. } \\
\text { loss* }\end{array}$ & $\begin{array}{c}\% \\
\text { moisture } \\
\text { loss } * \\
\end{array}$ & $\begin{array}{l}\% \text { wt. } \\
\text { loss* }\end{array}$ \\
\hline Tectona grandis & $28.34 \pm 0.7$ & $4.1 \pm 0.8$ & $4.1 \pm 0.2$ & $4.7 \pm 0.7$ & $3.33 \pm 0.5$ & $6.96 \pm 0.8$ \\
\hline \multirow[t]{2}{*}{ Terminalia arjuna } & $21.25 \pm 0.2$ & $1.0 \pm 0.5$ & $3.3 \pm 0.5$ & $2.0 \pm 0.8$ & $5.36 \pm 0.8$ & $3.86 \pm 0.9$ \\
\hline & \multicolumn{6}{|c|}{ Lenzites sterioides } \\
\hline T. grandis & $3.76 \pm 0.6$ & $2.3 \pm 0.1$ & $3.71 \pm 0.7$ & $3.8 \pm 0.8$ & $5.48 \pm 0.8$ & $6.57 \pm 0.3$ \\
\hline \multirow[t]{2}{*}{ T. arjuna } & $5.84 \pm 0.8$ & $7.2 \pm 0.4$ & $3.16 \pm 0.2$ & $11.4 \pm 0.5$ & $6.53 \pm 0.5$ & $9.25 \pm 0.5$ \\
\hline & \multicolumn{6}{|c|}{ Hexagonia apiaria } \\
\hline T. grandis & $10.05 \pm 0.3$ & $5.85 \pm 0.3$ & $7.85 \pm 0.7$ & $8.25 \pm 0.4$ & $4.89 \pm 0.3$ & $9.12 \pm 0.6$ \\
\hline \multirow[t]{2}{*}{ T. arjuna } & $16.08 \pm 0.8$ & $3.5 \pm 0.7$ & $10.24 \pm 0.5$ & $4.5 \pm 0.2$ & $8.98 \pm 0.2$ & $8.05 \pm 0.3$ \\
\hline & \multicolumn{6}{|c|}{ Trichoderma viride } \\
\hline T. grandis & $25.17 \pm 0.5$ & $4.1 \pm 0.2$ & $15.87 \pm 0.8$ & $4.4 \pm 0.5$ & $3.77 \pm 0.6$ & $6.41 \pm 0.7$ \\
\hline T. arjuna & $47.08 \pm 0.8$ & $1.3 \pm 0.3$ & $3.18 \pm 0.2$ & $2.2 \pm 0.3$ & $2.81 \pm 0.7$ & $2.5 \pm 0.5$ \\
\hline
\end{tabular}

* indicates each component values are based on the three replicates. Uninoculated wooden blocks were incubated for 20 and 40 days to act as a control.

\pm Results were significant at $\mathrm{P}<0.05$ level by one way ANOVA

Histogram 2. The \% weight loss of two wood blocks infected with lignicolous fungi.

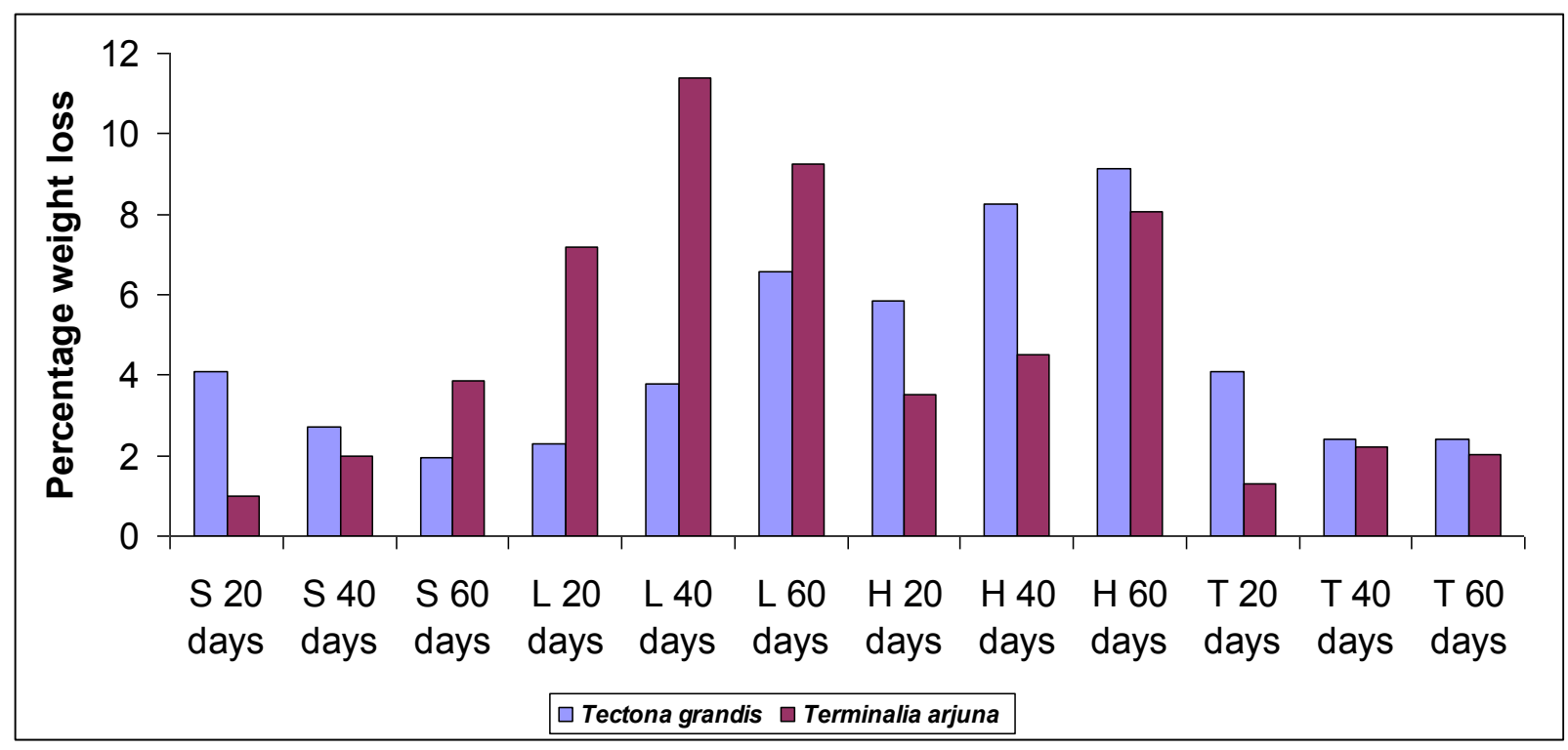


Percentage wood decay of three different woods $T$. grandis $T$. bellerica and T. arjuna was infected by white rot fungi like $L$. stereoides, $C$. versicolor and $H$. apiaria for 3, 6, 12 months. After 12 months $90 \%$ of wood was decayed in T. arjuna due to L. stereoides, followed by $T$. bellerica and T. grandis. Wood decay was minimum (16.82\%) in teak due to H. apiaria after 3 months of inoculation (Table 3 and Histogram 3 ).

Table 3. The \% weight loss in three wood blocks caused by three lignicolous fungi.

\begin{tabular}{|c|c|c|c|c|c|c|c|c|c|}
\hline \multirow{3}{*}{ Wood } & \multicolumn{9}{|c|}{ \% Weight loss } \\
\hline & \multicolumn{3}{|c|}{ Lenzites sterioides } & \multicolumn{3}{|c|}{ Coriolus versicolor } & \multicolumn{3}{|c|}{ Hexagonia apiaria } \\
\hline & 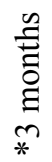 & 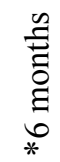 & 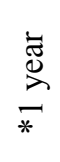 & 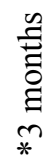 & 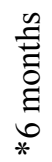 & 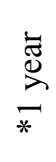 & 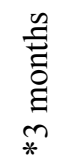 & 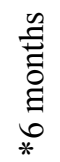 & $\frac{\vec{\Xi}}{\stackrel{D}{~}}$ \\
\hline 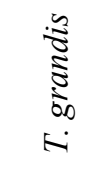 & 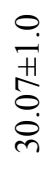 & $\begin{array}{l}\infty \\
\text { i } \\
\text { H̊ } \\
0 \\
\dot{0} \\
i\end{array}$ & $\begin{array}{l}\infty \\
\text { i } \\
+ \\
\infty \\
0 \\
\stackrel{N}{N}\end{array}$ & 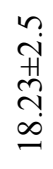 & 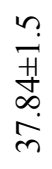 & 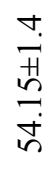 & $\begin{array}{l}n \\
\text { H } \\
\text { O } \\
0 \\
0\end{array}$ & $\begin{array}{l}0 \\
\text { i } \\
\text { tे } \\
\infty \\
\stackrel{i}{ }\end{array}$ & $\begin{array}{l}\infty \\
\sim \\
+ \\
\infty \\
\infty \\
\dot{J}\end{array}$ \\
\hline 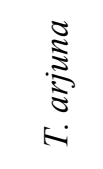 & 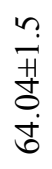 & $\begin{array}{l}\stackrel{+}{i} \\
\stackrel{+}{\circ} \\
\stackrel{i}{r}\end{array}$ & $\begin{array}{l}n \\
\text { in } \\
\text { ثे } \\
\stackrel{8}{8}\end{array}$ & 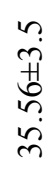 & 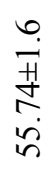 & $\begin{array}{l}\infty \\
\stackrel{\infty}{*} \\
\stackrel{0}{\circ} \\
\stackrel{0}{\circ}\end{array}$ & $\begin{array}{l}n \\
\text { मे } \\
\tilde{n} \\
\infty \\
+\end{array}$ & $\begin{array}{l}\stackrel{+}{i} \\
\stackrel{H}{\delta} \\
\infty \\
\dot{b}\end{array}$ & $\begin{array}{l}\infty \\
\text { से } \\
\infty \\
\stackrel{\infty}{2}\end{array}$ \\
\hline 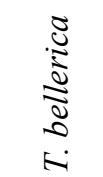 & $\begin{array}{l}n \\
\text { in } \\
\text { H } \\
\text { to } \\
\dot{m}\end{array}$ & $\begin{array}{l}n \\
\dot{y} \\
+n \\
n \\
n \\
n\end{array}$ & $\begin{array}{l}n \\
\stackrel{n}{H} \\
\frac{\infty}{\infty}\end{array}$ & $\begin{array}{l}\dot{+} \\
\text { in } \\
\tilde{n} \\
\stackrel{\sim}{\sim}\end{array}$ & 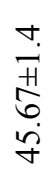 & 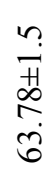 & $\begin{array}{l}\infty \\
\text { i } \\
+ \\
\infty \\
\infty \\
\infty \\
\dot{+}\end{array}$ & $\begin{array}{l}0 \\
\text { i } \\
H \\
\infty \\
\infty \\
i n \\
n\end{array}$ & $\begin{array}{l}\stackrel{+}{\sim} \\
\text { H } \\
\text { D } \\
\stackrel{\sim}{ }\end{array}$ \\
\hline
\end{tabular}

* indicates each component values are based on the three replicates. Uninoculated wooden blocks were incubated for 20 and 40 days to act as a control.

\pm Results were significant at $\mathrm{P}<0.05$ level by one way ANOVA

Histogram 3. The $\%$ weight loss in 3 wood blocks infected with lignicolous fungi.

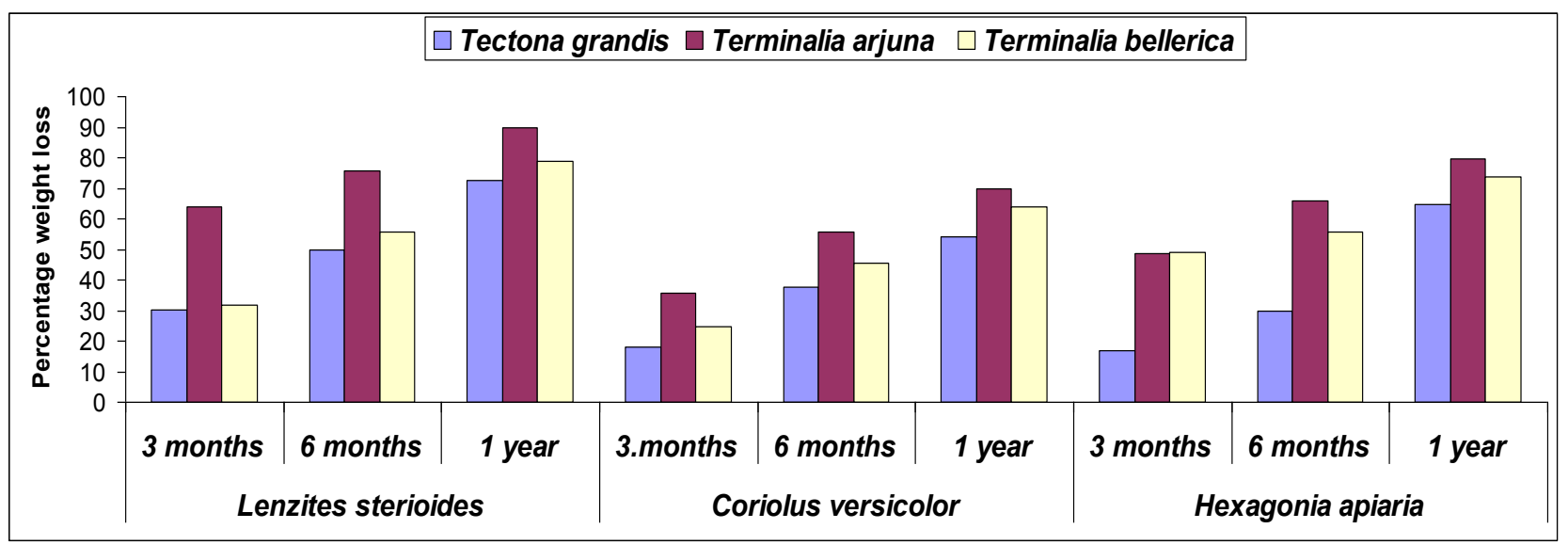


Biological agar block method allowed wood samples to be evaluated and monitored in terms of colonization and development of decay by $C$. versicolor and classified based on mean mass loss. In this research, the in vitro decay of five commercial woods by $C$. versicolor was studied by the agar block method. The selected wood samples were Abies alba. Populus alba, Fagus orientalis, Platanus orientalis and Ulmus glabra. There was a high correlation between the mass loss and apparent damage. Therefore biological evaluation of wood regarding biodegradation and selection of wood types for various applications will be of high priority (Olfat A.M., Karimi A.N., and Parsapajouh D. 2007). In the present study also there was a correlation between the weight loss and damage, so different biochemical test were studied to conform that biological evaluation of wood was necessary.

The Basidiomycetes, Poria carbonica and $C$. versicolor, caused substantial wood weight loss over the test period. These results were usually obtained by soil or vermiculite burial methods (Morrell J.J. and Zabel R.A. 1989). In the present study the wood chip and block method showed significant weight loss in seven woods infected by white rot and soft rot fungi. The decreasing weight in studied samples showed that $C$. versicolor can grow quickly and may rapidly affect the appearance and degrade the wood (Olfat A. M., and Karimi A.N., 2005). In the present study the growth of $C$. versicolor was quick to degrade the wood very fast when compared to other lignicolous fungi. The lowest weight loss decreasing was observed in $U$. glabra and highest value in $F$. orientalis. This was true for the study of crude oil and beech wood caused by C. versicolor (Olfat A. M., and Karimi A.N., 2005). In the present study also $C$. versicolor degrade $T$. arjuna wood very fast.

The percentage weight loss in inner heart wood and outer heart woods of New guinea teak was 44, 54 and 12, 21 for Coniophora olivacea and C. versicolor respectively. The percentage weight loss in inner heart wood and outer heart wood of Indonesian teak was 54, 55 and 22, 21 for $C$. olivacea and $C$. versicolor. The percentage weight loss of inner heart wood and outer heart wood of Burma teak was 4, 8 and 4, 3 for C. olivacea and C. versicolor respectively (Guilley et al. 2004). In the present study the heart wood of teak showed 72.68 $\%, 54.15 \%, 64.88 \%$ of weight loss by L. sterioides, C. versicolor and H. apiaria respectively. Based on percentage weight loss, the American Society for Testing Materials ASTM (1969) classified resistance of wood. Highly resistant wood showed weight loss of zero to $10 \%$, resistant wood shows weight loss of 11 to $24 \%$, moderately resistant wood showed 25 to $44 \%$ weight loss, and nonresistant wood showed $45 \%$ or greater weight loss. In the present study the teak and terminalia wood was moderately resistant to non resistant when infected with different lignicolous fungi in wood block test. The in vitro decay of five commercial woods by $C$. versicolor was studied by the agar block method showed strong resistance of $U$. glabra and lowest resistance in F. orientalis (Olfat A.M., Karimi A.N., and Parsapajouh D. 2007). In the present study teak wood infected with $C$. versicolor showed resistant to non resistant. Where as in terminalia wood infected with same fungi showed moderately resistant to nonresistant. Twelve hundred samples from 31 trees were exposed to four fungi: Pycnoporus sanguineus, Antrodia sp., Gloephylum trabeum, and Coriolus versicolor. Tests showed that Antrodia sp. and C. versicolor resulted in $<20 \%$ mass loss, whereas all samples were rated as durable or highly durable with regard to $P$. sanguineus and G. trabeum. Inner heartwood was found to be the most resistant to pathogen attack and outer heartwood the least (Kokutse, et al. 2006). In the present study teak wood infected with $L$. stereoides showed moderately resistant to nonresistant, with $C$. versicolor and $H$. apiaria showed resistant to non resistant.

So, the in vitro wood decay test cannot be taken as absolute evidence for the behavior of lignicolous fungi, they were useful to determine their wood-degrading properties. Weight 
loss of yellow-poplar samples incubated with $T$. versicolor in a soil-block test was significantly higher than that in an agar-block test. Therefore, the soil-block test was more sensitive to detect fungal decay in yellow-poplar under the conditions of the experiments (Schirp A. and Wolcott M. P. 2005). In the present study the most effective method was agar block method when compared to wood chip method.

\section{3. Biochemical analysis}

\section{3. 1. Artificially inoculated wood blocks}

The physicochemical analysis of teak, and pine woods infected with wood decay fungi was done. The details were recorded in Table 4 and 5.

Table 4. Physico-chemical analysis of sound wood of Tectona grandis, Adina cordifolia and Terminalia bellerica.

\begin{tabular}{|c|c|c|c|c|c|c|c|c|}
\hline \multirow[b]{2}{*}{ Plants } & \multirow[b]{2}{*}{ *Moisture \% } & \multirow[b]{2}{*}{$\mathrm{pH}$} & \multirow[b]{2}{*}{$\begin{array}{c}\text { *Swelling } \\
\text { capacity } \\
\%\end{array}$} & \multicolumn{5}{|c|}{$\%$ of dry weight } \\
\hline & & & & $\begin{array}{c}* \text { Acid } \\
\text { insoluble } \\
\text { lignin }\end{array}$ & *Holocellulose & $\begin{array}{c}\text { *Ethanol- } \\
\text { benzene } \\
\text { soluble } \\
\text { substrate }\end{array}$ & $\begin{array}{c}\text { *Hot water } \\
\text { soluble } \\
\text { substrate }\end{array}$ & $\begin{array}{l}* \text { Ash } \\
(\mathrm{g})\end{array}$ \\
\hline $\begin{array}{l}\text { Tectona } \\
\text { grandis } 1\end{array}$ & $6.1 \pm 0.26$ & 5.8 & $45.1 \pm 0.7$ & $\begin{array}{l}29.3 \\
\pm 0.9\end{array}$ & $143.2 \pm 1.8$ & $26.7 \pm 1.8$ & $7.8 \pm 1.0$ & $0.06 \pm 0.01$ \\
\hline T. grandis 2 & $6.5 \pm 0.25$ & 4.4 & $40.0 \pm 2$ & $\begin{array}{l}42.0 \\
\pm 0.24\end{array}$ & $112.5 \pm 2.5$ & $37.4 \pm 1.6$ & $9.5 \pm 1.4$ & $0.10 \pm 0.03$ \\
\hline $\mathrm{T}$. grandis 3 & $5.1 \pm 0.24$ & 5.2 & -- & $\begin{array}{l}43.2 \\
\pm 1.5\end{array}$ & -- & $17.2 \pm 2.7$ & $5.6 \pm 2.5$ & -- \\
\hline $\begin{array}{c}\text { Adina } \\
\text { cordifolia }\end{array}$ & $5.7 \pm 0.23$ & 5.3 & $35.5 \pm 1.4$ & $\begin{array}{l}35.0 \\
\pm 2.4\end{array}$ & $141.5 \pm 2.3$ & $32.1 \pm 2.4$ & $19.4 \pm 0.5$ & $0.21 \pm 0.04$ \\
\hline $\begin{array}{c}\text { Terminalia } \\
\text { bellerica }\end{array}$ & $7.8 \pm 0.51$ & 5.2 & $31.5 \pm 1.8$ & $\begin{array}{l}20.3 \\
\pm 1.2\end{array}$ & $153.0 \pm 2.8$ & $28.2 \pm 1.8$ & $20.7 \pm 0.35$ & $0.06 \pm 0.01$ \\
\hline $\begin{array}{c}\text { Pinus } \\
\text { longifolia }\end{array}$ & $5.8 \pm 0.4$ & 5.1 & -- & $\begin{array}{l}42.4 \\
\pm 1.8\end{array}$ & -- & $11.0 \pm 2.5$ & $4.4 \pm 0.2$ & -- \\
\hline
\end{tabular}

* indicates each component values are based on the three replicates.

\pm Results were significant at $P<.05$ level by one way ANOVA.

Table 5. Chemical analysis of decayed woods of Tectona grandis and Pinus longifolia by 4 lignicolous fungi.

\begin{tabular}{|c|c|c|c|c|c|c|c|c|}
\hline Plant & Fungi & days & $\begin{array}{c}* \% \\
\text { Moisture }\end{array}$ & $\mathbf{p H}$ & $\begin{array}{c}* \text { Hot water } \\
\text { soluble } \\
\text { substrate }\end{array}$ & $\begin{array}{c}* \text { Ethanol- } \\
\text { benzene } \\
\text { soluble } \\
\text { substrate }\end{array}$ & $\begin{array}{c}* \text { Acid } \\
\text { insoluble } \\
\text { lignin }\end{array}$ & $\begin{array}{c}* \text { Holo - } \\
\text { cellulose }\end{array}$ \\
\hline Pine & $*$ Control & & $5.8 \pm 0.8$ & 5.10 & $4.4 \pm 0.2$ & $11.0 \pm 1.4$ & $42.4 \pm 1.5$ & $4.5 \pm 0.8$ \\
\hline & $\begin{array}{c}\text { Lenzites } \\
\text { sterioides 2 }\end{array}$ & 20 & $5.9 \pm 0.4$ & 5.57 & $4.3 \pm 0.4$ & $8.2 \pm 1.8$ & $11.6 \pm 1.2$ & $7.5 \pm 1.5$ \\
\hline & L. sterioides 1 & 20 & $5.7 \pm 0.2$ & 5.16 & $3.8 \pm 0.8$ & $7.1 \pm 1.6$ & $25.6 \pm 1.8$ & $10.0 \pm 1.3$ \\
\hline
\end{tabular}




\begin{tabular}{|c|c|c|c|c|c|c|c|c|}
\hline & $\begin{array}{c}\text { Schizophyllum } \\
\text { commune }\end{array}$ & 20 & $4.5 \pm 0.6$ & 5.30 & $4.7 \pm 0.5$ & $7.3 \pm 2.4$ & $19.6 \pm 1.6$ & $5.0 \pm 1.8$ \\
\hline & $\begin{array}{c}\text { Trichoderma } \\
\text { viride }\end{array}$ & 20 & $6.2 \pm 1.2$ & 6.05 & $3.5 \pm 0.4$ & $7.1 \pm 2.6$ & $26.0 \pm 2.3$ & $11.5 \pm 1.4$ \\
\hline & H. apiaria & 20 & $5.5 \pm 2.5$ & 6.5 & $4.7 \pm 0.6$ & $8.5 \pm 1.5$ & $30 \pm 2.6$ & $15 \pm 1.0$ \\
\hline Teak & Control & & $5.1 \pm 0.2$ & 5.26 & $5.6 \pm 0.9$ & $17.2 \pm 2.2$ & $43.2 \pm 2.8$ & $12.5 \pm 1.6$ \\
\hline & L. sterioides 2 & 20 & $5.9 \pm 0.7$ & 6.01 & $4.9 \pm 0.3$ & $13.8 \pm 1.8$ & $13.0 \pm 1.5$ & $19.5 \pm 1.4$ \\
\hline & L. sterioides 1 & 20 & $5.5 \pm 0.6$ & 5.05 & $4.5 \pm 1.5$ & $12.2 \pm 1.4$ & $26.8 \pm 1.4$ & $10.5 \pm 1.8$ \\
\hline & S. commune & 20 & $5.9 \pm 0.1$ & 5.70 & $5.9 \pm 1.8$ & $17.4 \pm 2.3$ & $29.2 \pm 1.8$ & $19.0 \pm 2.0$ \\
\hline & T. viride & 20 & $6.2 \pm 1.5$ & 6.90 & $4.6 \pm 0.4$ & $14.0 \pm 2.5$ & $31.0 \pm 1.6$ & $14.0 \pm 2.5$ \\
\hline & H.apiaria & 20 & $5.3 \pm 1.8$ & 4.89 & $5.5 \pm 0.7$ & $15.6 \pm 1.8$ & $18.8 \pm 1.9$ & $7.0 \pm 1.0$ \\
\hline & H. apiaria & 40 & $9.6 \pm 2.5$ & 5.27 & $16.0 \pm 2.3$ & $18.4 \pm 1.5$ & $41.4 \pm 2.5$ & $15.5 \pm 2.3$ \\
\hline
\end{tabular}

* indicates each component values are based on the three replicates. Uninoculated wooden blocks were incubated for 20 and 40 days to act as a control.

\pm Results were significant at $\mathrm{P}<0.05$ level by one way ANOVA.

Highest percentage of moisture was shown by teak wood infected with $H$. apiaria whereas it was lowest in case of pine wood infected with $S$. commune. High acidic nature was shown by teak wood infected with $H$. apiaria in 20 days. Almost neutral nature was shown by teak wood infected with $T$. viride. The percentage loss of ethanol - benzene soluble substrates was more in case of teak wood decayed by $H$. apiaria for 40 days, whereas, lowest was observed in pine wood decayed by L. stereoides 1 and T. viride. The highest percentage loss of acid insoluble lignin was observed in case of teak wood decayed by H. apiaria for 40 days, whereas, lowest in case of teak wood inoculated with L. stereoides 2 . Where as highest percentage loss of Acid insoluble lignin was observed incase of pine woods decayed by $H$. apiaria and lowest incase of pine wood inoculated with L. stereoides 2 . The percentage loss of holocellulose was more in case of teak wood infected with L. stereoides 2, whereas, lowest in case of wood decayed by H. apiaria. The highest loss of holocellulose in pine wood was observed by $H$. apiaria decay and lowest in case of $S$. commune decay

Three white rot fungi Daedalea elegans, Polyporus glaganetus, and L. betulina were screened for their lignin degrading abilities on rice straw, maize cob, sawdust of Terminalia superba and sugarcane bagasse at different time intervals (30,60 and 90 days). All the fungi demonstrated varying levels of ligninolytic capability with different degrees of lignin degradation in all the fermented substrates. The highest lignin reduction of $92.9 \%$ was recorded in maize cob fermented with D. elegans after 90 days (Adejoye O.D. and Fasidi I.O. 2009). But in the present study only $26 \%$ of reduction in lignin was observed in pine and teak wood blocks infected by L. stereoides, $30 \%$ loss in pine and $18 \%$ loss of lignin in teak woods infected by $H$. apiaria, $31 \%$ loss in teak and $26 \%$ loss of lignin in pine woods infected by $T$. viride

When a brown-rot-causing fungi Polyporus palustris was infected to Mangifera indica wood shavings for considerable periods, approximately 40 to $50 \%$ lignin loss was observed in two years (Ananthanarayanan, S.; Wajid, S.A.; Padmanabhan, S. 1978). The Mangifera wood blocks were infected with white-rot-causing fungi for 90 days, the utilization of lignin was $26 \%$ by $F$. flavus and $20 \%$ by S. commune (Padhiar A., Albert S., Nagadesi P. K. and 
Arya A. 2010). But in the present study the maximum lignin loss was recorded in teak than in pine by L. stereoides. The loss of lignin in teak and pine wood infected by $S$. commune was $29.2 \%$ and $19.6 \%$ respectively.

\section{3. 2. Artificially infected wood Planks}

The artificially infected wood log of Tectona, Adina, T. crenulata and T. arujna were chemically analyzed. The percentage of moisture loss was highest in case of $T$. crenulata wood decayed by L. stereoides, whereas, lowest in case of teak wood decayed by $C$. versicolor. The acidic nature was shown by $T$. crenulata wood decayed by $C$. versicolor, whereas, basic nature was shown by teak wood infected with $L$. stereoides. The percentage loss in hot water soluble substrates was more in case of $T$. crenulata due to L. stereoides for 5 months, whereas, lowest in case of teak wood decayed by H. apiaria for 5 months. The percentage loss in ethanol-benzene soluble substrate was more in case of Adina wood decayed by $C$. versicolor in 5 months. Whereas, lowest in case of teak wood infected with $L$. stereoides for 3 months. The percentage loss of acid soluble lignin was more in case of $T$. crenulata wood decayed by $L$. sterioides for 5 months, whereas, lowest in case of teak wood decayed by $L$. stereoides for 3 months. The percentage loss in holocellulose was more in case of Adina wood decayed by $C$. versicolor, whereas, least in case of $T$. crenulata wood infected with $C$. versicolor for 5 months and T. pini for 5 months period (Table 6 and Histogram 4).

Table 6. Chemical analysis of three woods decayed by lignicolous for 5 months.

\begin{tabular}{|c|c|c|c|c|c|c|c|c|}
\hline Plant & Fungi & Months & $\begin{array}{c}* \% \\
\text { Moisture }\end{array}$ & $\mathbf{p H}$ & $\begin{array}{c}* \text { Hot } \\
\text { water } \\
\text { soluble } \\
\text { substrate }\end{array}$ & $\begin{array}{c}\text { *Ethanol- } \\
\text { benzene } \\
\text { soluble } \\
\text { substrate }\end{array}$ & $\begin{array}{c}* \text { Acid } \\
\text { insoluble } \\
\text { lignin }\end{array}$ & $\begin{array}{c}* \text { Holo - } \\
\text { cellulose }\end{array}$ \\
\hline $\begin{array}{c}\text { Tectona } \\
\text { grandis }\end{array}$ & $*$ Control & 3 and 5 & $5.1 \pm 0.8$ & 5.26 & $5.6 \pm 0.6$ & $17.2 \pm 1.5$ & $43.2 \pm 1.3$ & $12.5 \pm 0.8$ \\
\hline & L. sterioides & 3 & $4.0 \pm 0.4$ & 9.08 & $10.5 \pm 0.3$ & $17.7 \pm 1.3$ & $20.8 \pm 1.8$ & $19.5 \pm 1.5$ \\
\hline & C. versicolor & 3 & $3.5 \pm 0.6$ & 8.30 & $10.3 \pm 0.7$ & $27.9 \pm 1.8$ & $30.4 \pm 2.5$ & $14.0 \pm 1.4$ \\
\hline & T. pini & 5 & $4.2 \pm 0.2$ & 8.10 & $5.8 \pm 0.8$ & $27.9 \pm 1.6$ & $36.4 \pm 2.4$ & $18.5 \pm 1.7$ \\
\hline & H. apiaria & 5 & $3.8 \pm 0.5$ & 6.87 & $2.5 \pm 0.4$ & $21.7 \pm 2.5$ & $27.2 \pm 3.0$ & $22.5 \pm 3.2$ \\
\hline $\begin{array}{c}\text { Adina } \\
\text { cordifolia }\end{array}$ & $*$ Control & 3 and 5 & $5.7 \pm 0.1$ & 5.30 & $19.4 \pm 0.8$ & $32.1 \pm 2.3$ & $35.0 \pm 2.5$ & $41.5 \pm 3.6$ \\
\hline & L. sterioides & 3 & $3.6 \pm 0.3$ & 5.98 & $8.6 \pm 0.2$ & $19.9 \pm 2.8$ & $42.4 \pm 2.4$ & $24.0 \pm 2.5$ \\
\hline & C. versicolor & 5 & $5.0 \pm 0.4$ & 4.60 & $15.9 \pm 0.5$ & $38.1 \pm 2.5$ & $33.6 \pm 1.6$ & $48.5 \pm 2.7$ \\
\hline & T. pini & 5 & $4.7 \pm 0.6$ & 4.67 & $18.4 \pm 0.6$ & $25.7 \pm 1.8$ & $33.8 \pm 1.4$ & $25.5 \pm 3.4$ \\
\hline & H. apiaria & 3 & $4.9 \pm 0.7$ & 5.60 & $9.3 \pm 0.2$ & $20.7 \pm 1.6$ & $29.2 \pm 1.8$ & $26.5 \pm 1.8$ \\
\hline $\begin{array}{c}\text { Terminalia } \\
\text { crenulata }\end{array}$ & $*$ Control & 5 & $6.5 \pm 0.7$ & 5.20 & $25.7 \pm 0.4$ & $30.0 \pm 2.5$ & $40.5 \pm 2.5$ & $35.0 \pm 1.6$ \\
\hline & L. sterioides & 5 & $5.5 \pm 0.2$ & 5.86 & $22.2 \pm 0.7$ & $23.7 \pm 1.9$ & $74.0 \pm 2.8$ & $20.0 \pm 2.5$ \\
\hline & C. versicolor & 5 & $4.3 \pm 0.4$ & 4.50 & $9.2 \pm 0.3$ & $24.4 \pm 2.5$ & $55.0 \pm 2.9$ & $10.5 \pm 2.5$ \\
\hline & T. pini & 5 & $4.8 \pm 0.8$ & 4.56 & $16.5 \pm 0.8$ & $20.4 \pm 2.6$ & $24.8 \pm 2.5$ & $28.5 \pm 1.8$ \\
\hline
\end{tabular}

* indicates each component values are based on the three replicates. Uninoculated wooden blocks were incubated for 20 and 40 days to act as a control.

\pm Results were significant at $\mathrm{P}<0.05$ level by one way ANOVA. 
Histogram 4. The \% loss of Acid insoluble lignin in 2 woods infected with lignicolous fungi.

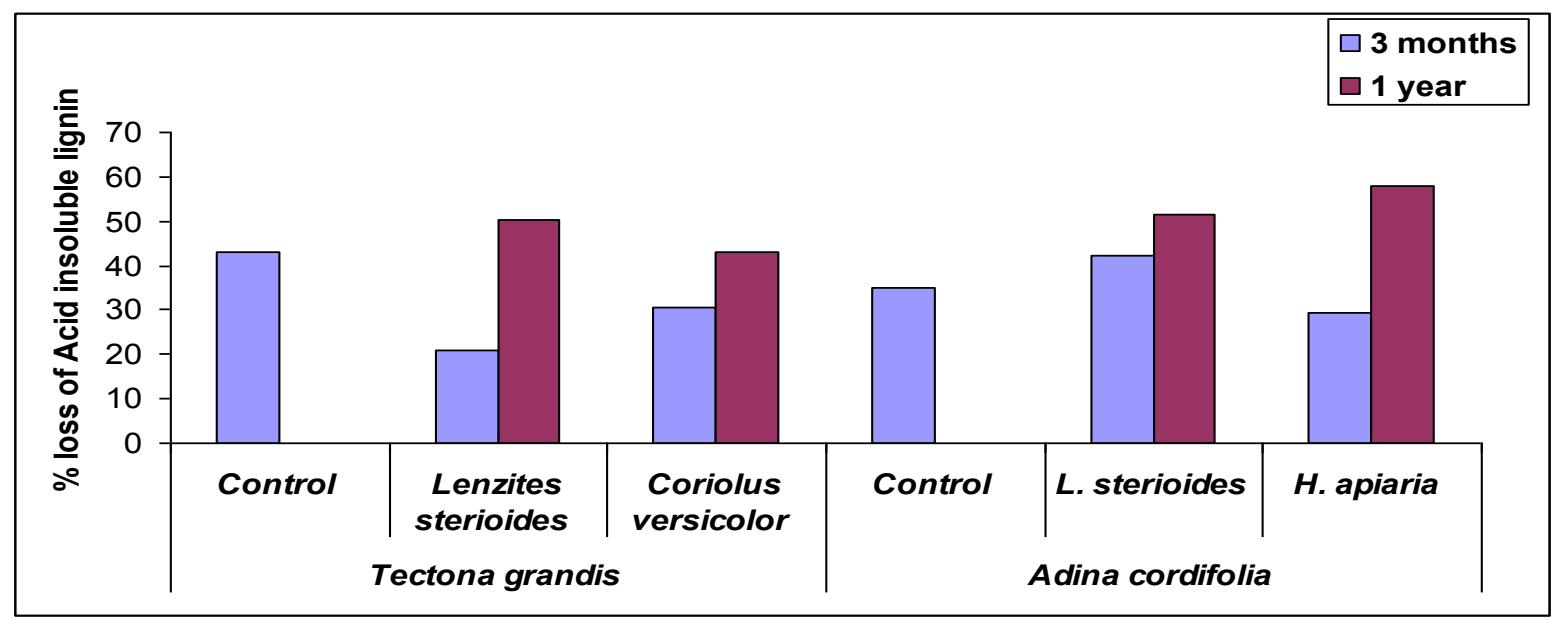

When $S$. commune was grown on liquid media containing ${ }^{14} \mathrm{C}$-lignin-labeled wood, the degradation of lignin was low and variable (Boyle, C.D.; Kropp, B.R.; and Reid, I.D. 1992). $S$. commune has ability to produce lignin degrading enzymes for degradation of lignocellulosic materials (Padhiar A., Albert S., Nagadesi P. K. and Arya A. 2010). In the present study as the incubation period was increase the loss of lignin also increase. After five months, the highest lignin loss was observed in $T$. crenulata infected with $L$. stereoides.

The chemical analysis of artificially inoculated wood blocks for 1 year was studied (Table 7). As the incubation period increased the percentage loss in acid soluble lignin was more in case of all infected woods reaching to almost $50 \%$. Whereas, the percentage loss of holocellulose was up to $20 \%$ only (Histogram 5).

Histogram 5. The \% loss of Acid insoluble lignin in woods infected with lignicolous fungi.

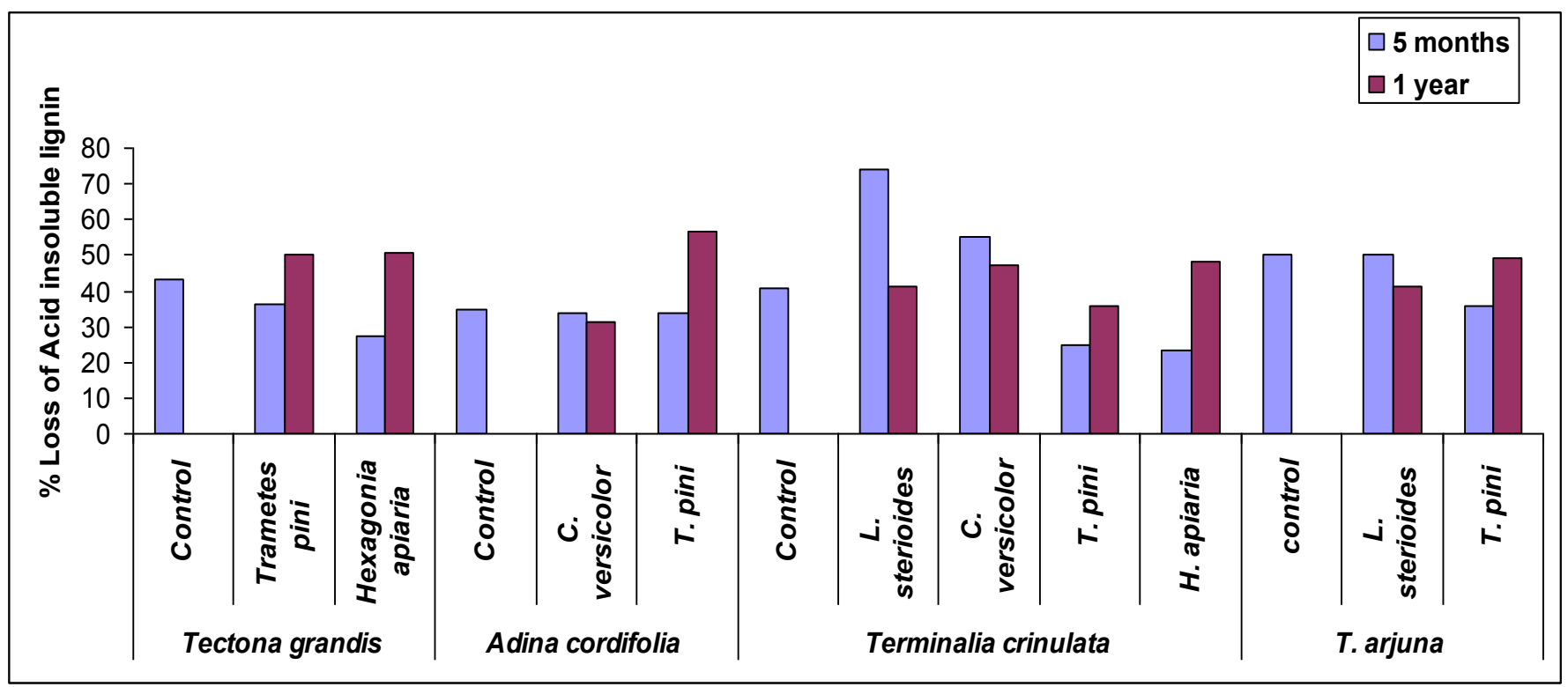


Table 7. Chemical analysis of four woods decayed by lignicolous fungi for one year.

\begin{tabular}{|c|c|c|c|c|c|c|c|}
\hline Plant & fungi & $\begin{array}{c}\% \\
\text { Moisture }\end{array}$ & pH & $\begin{array}{c}\text { Hot water } \\
\text { soluble } \\
\text { substrate }\end{array}$ & $\begin{array}{l}\text { Ethanol- benzene } \\
\text { soluble substrate }\end{array}$ & $\begin{array}{c}\text { Acid } \\
\text { insoluble } \\
\text { lignin }\end{array}$ & $\begin{array}{c}\text { Holo - } \\
\text { cellulose }\end{array}$ \\
\hline \multirow[t]{5}{*}{$\begin{array}{l}\text { Tectona } \\
\text { grandis }\end{array}$} & Control & $5.1 \pm 0.8$ & 5.26 & $5.6 \pm 1.2$ & $17.2 \pm 1.2$ & $43.2 \pm 2.5$ & $12.5 \pm 1.2$ \\
\hline & L. sterioides & $5.7 \pm 0.2$ & 5.66 & $10 \pm 1.6$ & $17.86 \pm 1.5$ & $50.4 \pm 2.8$ & $8.0 \pm 1.4$ \\
\hline & C. versicolor & 4.80 .4 & 5.88 & $6.6 \pm 1.2$ & $17.33 \pm 1.9$ & $43.0 \pm 2.6$ & $12.5 \pm 1.6$ \\
\hline & T. pini & $4.8 \pm 0.5$ & 5.54 & $6.0 \pm 0.8$ & $18.66 \pm 1.3$ & $50.4 \pm 2.8$ & $16.5 \pm 1.8$ \\
\hline & H. apiaria & $4.5 \pm 0.6$ & 5.36 & $7.4 \pm 0.3$ & $15.20 \pm 1.7$ & $50.8 \pm 2.5$ & $9.0 \pm 1.5$ \\
\hline \multirow[t]{5}{*}{$\begin{array}{c}\text { Adina } \\
\text { cordifolia } \\
\end{array}$} & Control & $5.7 \pm-0.2$ & 5.30 & $19.4 \pm 1.8$ & $32.1 \pm 1.4$ & $35.0 \pm 2.1$ & $41.5 \pm 1.8$ \\
\hline & L. sterioides & $6.1 \pm 0.1$ & 4.93 & $12.8 \pm 1.4$ & $18.53 \pm 1.6$ & $51.4 \pm 2.6$ & $15.5 \pm 1.6$ \\
\hline & C. versicolor & $35.0 \pm 1.5$ & 4.89 & $39.6 \pm 2.4$ & $28.53 \pm 1.8$ & $31.2 \pm 2.7$ & $46.2 \pm 2.5$ \\
\hline & T. pini & $14.8 \pm 1.4$ & 4.99 & $16.4 \pm 1.6$ & $13.80 \pm 1.4$ & $56.6 \pm 2.4$ & $15.0 \pm 1.4$ \\
\hline & H. apiaria & $19.5 \pm 1.8$ & 4.95 & $23.0 \pm 1.5$ & $7.20 \pm 1.6$ & $57.8 \pm 2.8$ & $14.0 \pm 1.9$ \\
\hline \multirow[t]{5}{*}{$\begin{array}{l}\text { Terminalia } \\
\text { crenulata }\end{array}$} & Control & $6.5 \pm 0.6$ & 5.20 & $25.7 \pm 1.3$ & $30.0 \pm 1.3$ & $40.5 \pm 2.6$ & $35.0 \pm 2.8$ \\
\hline & L. sterioides & $7.1 \pm 1.2$ & 5.42 & $13.4 \pm 1.7$ & $18.60 \pm 1.6$ & $41.0 \pm 2.7$ & $23.0 \pm 2.4$ \\
\hline & C. versicolor & $8.9 \pm 1.4$ & 4.91 & $16.6 \pm 1.8$ & $19.20 \pm 1.4$ & $47.0 \pm 2.4$ & $28.5 \pm 2.7$ \\
\hline & T. pini & $14.7 \pm 2.5$ & 4.92 & $19.8 \pm 2.6$ & $16.20 \pm 1.7$ & $35.8 \pm 2.6$ & $6.0 \pm 0.8$ \\
\hline & H. apiaria & $10.2 \pm 1.5$ & 5.10 & $13.8 \pm 2.8$ & $11.80 \pm 1.5$ & $48.2 \pm 2.8$ & $7.0 \pm 0.6$ \\
\hline \multirow[t]{3}{*}{ T. arjuna } & Control & $2.2 \pm 0.4$ & 5.50 & $9.3 \pm 2.5$ & $22.5 \pm 1.0$ & $50.0 \pm 2.5$ & $22.0 \pm 2.4$ \\
\hline & L. sterioides & $6.7 \pm 1.2$ & 5.50 & $13.8 \pm 2.8$ & $10.60 \pm 1.4$ & $41.2 \pm 2.2$ & $16.5 \pm 2.8$ \\
\hline & T. pini & $7.7 \pm 1.8$ & 5.21 & $13.4 \pm 2.4$ & $28.73 \pm 1.2$ & $49.0 \pm 2.7$ & $14.0 \pm 2.7$ \\
\hline
\end{tabular}

* indicates each component values are based on the three replicates. Uninoculated wooden blocks were incubated for 20 and 40 days to act as a control.

\pm Results were significant at $\mathrm{P}<0.05$ level by one way ANOVA.

The highest percentage of hot water soluble substrates in teak wood was $10 \%$ when infected with $L$. stereoides whereas lowest incase of $T$. pini infected wood $(6.0 \%)$. The highest percentage of hot water soluble substrates in Adina wood was $39.6 \%$ when infected with $C$. versicolor whereas lowest incase of $L$. stereoides infected wood (12.8). The highest percentage of hot water soluble substrates in T. crenulata wood was $19.8 \%$ when infected with $T$. pini whereas lowest incase of $L$. stereoides infected wood $(13.4 \%)$. The highest percentage of hot water soluble substrates in T. arjuna wood was $13.8 \%$ when infected with L. stereoides. The highest percentage of ethanol- benzene soluble substrate in teak wood was $18.6 \%$ when infected with $T$. pini whereas lowest incase of $H$. apiaria infected wood (15.2 $\%)$. The highest percentage of ethanol- benzene soluble substrate in Adina wood was 28.5 $\%$ when infected with $C$. versicolor whereas lowest incase of $H$. apiaria infected wood (7.2 $\%)$. The highest percentage of ethanol- benzene soluble substrate in T. cenulata wood was 
$19.2 \%$ when infected with $C$. versicolor whereas lowest incase of $H$. apiaria infected wood (11.8\%). The highest percentage of ethanol- benzene soluble substrate in T. arjuna wood was $28.73 \%$ when infected with $T$. pini. The highest percentage loss of lignin in teak wood was $54.8 \%$ when infected with $H$. apiaria; whereas lowest in case of $C$. versicolor infected wood $(43.0 \%)$.

The highest percentage loss of lignin in Adina wood was $57.8 \%$ when infected with $H$. apiaria, whereas lowest incase of $C$. versicolor infected wood $(31.2 \%)$. The highest percentage loss of lignin in $T$. crenulata wood was $48.2 \%$ when infected with $H$. apiaria, whereas lowest incase of $T$. pini infected wood $(35.8 \%)$. The highest percentage loss of lignin in $T$. arjuna wood was $49.0 \%$ when infected with $T$. pini. The highest percentage loss of holocellulose in teak wood was $16.5 \%$ when infected with $T$. pini. whereas lowest incase of $L$. stereoides infected wood $(8.0 \%)$. The highest percentage loss of holocellulose in Adina wood was $46.2 \%$ when infected with $C$. versicolor, whereas lowest in case of $H$. apiaria infected wood (14.0\%). The highest percentage loss of holocellulose in T. crenulata wood was $28.5 \%$ when infected with $C$. versicolor. whereas lowest incase of $T$. pini infected wood $(6.0 \%)$. The highest percentage loss of holocellulose in T. arjuna wood was $16.5 \%$ when infected with $L$. stereoides.

White rot fungi $F$. flavus and $S$. commune selectively degraded the lignin of Syzygium cumini rather than the holocellulose component, whereas simultaneous degradation of lignin occurred in the case of M. indica (Padhiar A., Albert S., Nagadesi P. K. and Arya A. 2010). In the present study the $L$. stereoides, $C$. versicolor, and $H$. apiaria showed the selective delignification in all artificially inoculated woods, whereas, $T$. pini showed simultaneous degradation of lignin in all woods tested. After 90 days of pretreatment with $F$. flavus, loss in lignin content was $25.7 \%$ in $M$. indica wood. However, $8 \%$ loss of holocellulose was caused by S. commune in S. cumini wood. (Padhiar A., Albert S., Nagadesi P. K. and Arya A. 2010). In the present study after 1 year of pretreatment with $H$. apiaria, loss in lignin content was 58 $\%$ in Adina wood.

However $6 \%$ loss of holocellulose was caused by $T$. pini in $T$. crenulata wood. Adaskaveg et al. (1990) observed selective delignification and simultaneous decay in oak wood infected with Ganoderma isolates. In decay of oak wood, for simultaneous decay, the ratio of Klason lignin (\% KL) to Chlorite Holocellulose (\% CHC) obtained was $1: 1$ by $G$. meredithiae; for moderate amount of delignification the ratio was 1.5:1 by G. zonatum; and for high amount of delignification 2.5 to 5:1 by G. colossum and G. oregonense. After 90 days of incubation, both the white-rot fungi degraded a moderate amount of lignin in $M$. indica wooden blocks, while in S. cumini a moderate amount of delignification was shown by F. flavus and S. commune (Padhiar A., Albert S., Nagadesi P. K. and Arya A. 2010).

In the present study the white rot fungi degraded highest amount of lignin in teak, adina, terminalia woods. The chemical analysis decayed wood showed highest delignification (i.e. Loss of Klason lignin) up to $84.71 \%$ by L. stereoides in teak wood (20) but in the present study showed delignification up to $50.4 \%$ only by L. stereoides in teak wood, but highest amount of delignification was shown by $H$. apiaria.

The maximum percentage of lignin loss by D. confragosa \& Phellinus pectinatus was found to be in wood shavings Bamboo clum - PDA + Hydrofluoric acid (41.66 \% \& $33.33 \%$ respectively) (Albert S. and Padhiar A. 2012). The highest percentage loss of lignin in teak, Adina, $T$. crenulata wood was $54.8 \%, 57.8 \%, 48.2 \%$ respectively when infected with $H$. apiaria where as in T. arjuna wood was $49.0 \%$ when infected with $T$. pini. 


\section{CONCLUSIONS}

The wood degrading capacity of lignicolous fungi was studied by decay test. In which two methods were followed, i) wood chips method ii) wood block method. For rapid detection of decay in wood, the wood chips method was best. When we compare Soil Block method, Agar Block method and wood chip method, the agar block method was best to study decay pattern and Biochemical changes in wood. As the fungi required suitable conditions like suitable temperature, moisture, $\mathrm{pH}$ for better growth and also for decay of wood. In the present paper in initial stages of decay the percentage of moisture was more, whereas in advanced stages of decay the \% moisture was less. As the percentage moisture was less percentage weight loss was also less, this indicates that the decay capacity of fungi depend on $\%$ moisture content in wood. Based on the weight loss studies different scientists have explained that the woods were resistant to a particular fungi. But in present study it was found that in case of lesser weight loss also wood was severely degraded by the lignicolous fungi. Therefore, on the basis of weight loss studies alone the type of wood decay can not be certainly decided. As the incubation period increased the percentage loss in acid soluble lignin was more in case of all infected woods. L. stereoides, C. versicolor, and H. apiaria showed the selective delignification in all infected woods, whereas, $T$. pini showed simultaneous degradation of lignin in all woods tested. The valuable timber like teak wood was not resistant to wood decay by lignicolous fungi used because they utilized $50 \%$ of lignin. For the second time the ability of wood decay by soft rot fungi like $T$. viride was described. For the first time the biochemical changes like loss of klason lignin and holocellulose from $T$. viride infected woods was described. For the first time the wood decay and biochemical changes in T. crenulata, T. bellerica, and T. arjuna woods infected by $L$. sterioides, C. versicolor H. apiaria T. pini, S. commune, and T. viride was described.

\section{Acknowledgements}

The authors are thankful to the Head, Department of Botany, The Maharaja Sayajirao University of Baroda for laboratory facilities and to Department of Science and Technology, New Delhi for providing financial support.

\section{References}

[1] D. Kaimowitz, XII world Forestry congress. Quebec city Canada. (2003) pp. 10-16.

[2] FAO - Available at: <http://faostat.fao.org/site/381/default.aspx> (2007).

[3] ITTO - STCP Report, in print (2006).

[4] K. Natarajan, K. Kolandavelu, CAS in Botany University of Madras, Chennai. (1998) pp 133.

[5] T. Timells, Wood Science and Technology, (1967).

[6] E. Alder, Wood Science and Technology 11 (1977) 169-218.

[7] H.E. Desch, J. M. Dinwoodie, MacMillan Press Ltd., London, (1996) pp. 306.

[8] R.A. Blanchette, Annual Reviews of Phytopathology 29 (1991) 381-398.

[9] R. A., Eaton, M. D. C. Hale, Chapman \& Hall, London, United Kingdom, 1993, pp. 546. 
[10] R. A. Zabel, J. J. Morrell, Academic Press, San Diego, California, 1992, pp. 476.

[11] W. W. Wilcox, USDA Forest Products Laboratory (Madison). Research Paper FPL 70 1968, pp. 46.

[12] W. E., Eslyn, T. K., Kirk, M. J. Effland, Phytopathology 65 (1975) 473-476.

[13] T. Nilsson, T. G. Daniel, Holzforschung 43 (1989) 11-18.

[14] T. K., Kirk, H.M. Chang, Butterworth-Heinemann, Boston, Massachusetts, 1990, pp. 666.

[15] R.A. Blanchette, Applied Environmental Microbiology 48 (1984) 647-653.

[16] I. Dill, G. Kraepelin, Applied and Environmental Microbiology 86 (1986) 1305-1312.

[17] B. E. Etter, Mycologia 21(4) (1929) 197-203.

[18] K. Seifert, Holz rohwerks 26 (1983) 208-215.

[19] ASTM, ASTM designation, D- (1969), 2017-2063.

[20] P. K. Nagadesi, A. Arya, S. Albert, Journal of the Indian Academy of Wood Science 1 (2013) 45-70.

[21] B.K. Bakshi, Y.N. Puri, S. Singh, Indian forester 93 (1967) 305-328.

[22] R.A. Blanchette, C.G. Shaw, Phytopathology 68 (1978) 631-637.

[23] E. A., Emerhi, B. A. Ekeke, B. A. Oyebade, African Journal of Biotechnology 7(10) (2008) 1512-1515.

[24] N. Reddy, Y. Yang, Bioresearch and Technology 100(14) (2009) 3593-3598.

[25] J. P. H. van Wyk, Trend in Biotechnology 19(5) (2001) 172-177.

[26] V. Bohdan, D. Yaser, International Journal of Energy and Environment 2(3) (2011) 427-446.

[27] A.M. Olfat, A.N. Karimi, D. Parsapajouh, Pakistan Journal of Biological Science 10(6) (2007) 1073-1077.

[28] J.J. Morrell, R.A. Zabel, Wood and Fiber Science 17 (1985) 132-143.

[29] A. M. Olfat, A.N. Karimi, Pakistan Journal of Biological Science 8 (2005) 1453-1456.

[30] E. Guilley, J. P. Charpentier, Wood Science and Technology 38 (2004) 539-554.

[31] A.D. Kokutse, A. Stokes, Trees 20 (2006) 219-223.

[32] A. Schirp M. P. Wolcott, Wood and Fiber Science 37(4) (2005) 643-652.

[33] O.D. Adejoye, I.O. Fasidi Bioresources 4 (2) (2009) 816-824.

[34] S. Ananthanarayanan, S.A. Wajid, S. Padmanabhan, Wood Science and Technology 4 (1970) 213-215.

[35] A. Padhiar, S. Albert, Journal of Wood Chemistry and Technology 30(2) (2010) 129-139.

[36] C.D. Boyle, B.R. Kropp, I.D. Reid, Applied Environmental Microbiology 58 (1992) 3217-3224. 
[37] J.E. Adaskaveg, R.L. Gilbertsonand, Applied Environmental Microbiology 56(6) (1990) 1932-1943.

[38] S. Albert, A. Padhiar, International Journal of Applied Biology and Pharmaceutical Technology 3(4) (2012) 369-375.

[39] Shivaraj Ninganagouda, Vandana Rathod, Dattu Singh, International Letters of Natural Sciences 10 (2014) 49-57

( Received 16 May 2014; accepted 23 May 2014 ) 